\title{
Serum anti-Toxoplasma gondii antibodies in Passer domesticus (Linnaeus, 1758) (Passeriformes: Passeridae), in the municipality of Pelotas, RS, Brazil*
}

\author{
Anticorpos séricos anti-Toxoplasma gondii em pardais, Passer \\ domesticus (Linnaeus, 1758) (Passeriformes: Passeridae), do \\ município de Pelotas, RS, Brasil
}

\author{
Luciana Siqueira Silveira dos Santos ${ }^{1}$ (D); Herbert Sousa Soares ${ }^{2}$ (D); Carolina Silveira Mascarenhas ${ }^{1}$ (D); \\ Paulo Roberto Silveira dos Santos ${ }^{3}$ (D); Solange Maria Gennari²,4 (D); Nara Amélia da Rosa Farias ${ }^{1}$
${ }^{1}$ Universidade Federal de Pelotas, Instituto de Biologia, Departamento de Microbiologia e Parasitologia, Pelotas - RS, Brazil Animal, São Paulo - SP, Brazil
${ }^{3}$ Instituto Chico Mendes de Conservação da Biodiversidade, Centro Nacional de Pesquisa para a Conservação das Aves Silvestres, Cabedelo - PB, Brazil
${ }^{4}$ Universidade Santo Amaro, Programa de Mestrado em Medicina e Bem-Estar Animal, São Paulo - SP, Brazil \\ ${ }^{2}$ Universidade de São Paulo, Faculdade de Medicina Veterinária e Zootecnia, Departamento de Medicina Veterinária Preventiva e Saúde
}

\begin{abstract}
The objective of this study was to detect the presence of anti-Toxoplasma gondii antibodies in serum samples from 100 house sparrows (Passer domesticus Linnaeus, 1758) that were caught in the municipality of Pelotas, Rio Grande do Sul, Brazil. The modified agglutination test (MAT) was used to investigate anti- $T$. gondii antibodies and samples with a cut-off dilution $>5$ were considered positive. Among the 100 serum samples analyzed, $80(80 \%)$ were reactive. These results demonstrate that $P$. domesticus may play an important role in the epidemiological chain of $T$. gondii, since it is widely distributed throughout Brazil, and may act as a source of infection to domestic and wild felids.
\end{abstract}

Keywords: Toxoplasmosis. Birds. Epidemiology. Public health. Urban environment.

\section{RESUMO}

O objetivo deste estudo foi detectar a presença de anticorpos anti-Toxoplasma gondii em amostras de soro de 100 pardais (Passer domesticus Linnaeus, 1758) capturados na área urbana do município de Pelotas, Rio Grande do Sul, Brasil. Para a pesquisa de anticorpos anti-T. gondii foi utilizado o teste de aglutinação modificado (MAT) e foram consideradas positivas as amostras que apresentaram título $>5$. Das 100 amostras de soro analisadas, $80(80 \%)$ foram reagentes. Esses resultados demonstram que $P$. domesticus, por ser amplamente distribuído em todo país, pode desempenhar um papel importante na cadeia epidemiológica de T. gondii, podendo atuar como fonte de infecção para felinos domésticos e silvestres.

Palavras-chave: Toxoplasmose. Aves. Epidemiologia. Saúde pública. Ambiente urbano.

Correspondence to:

Luciana Siqueira Silveira dos Santos

Universidade Federal de Pelotas, Instituto de Biologia,

Departamento de Microbiologia e Parasitologia

Campus Universitário do Capão do Leão, Travessa André

Dreyfus, s/n, Capão do Leão

CEP: 96160-000, Pelotas - RS, Brazil

e-mail: sssluciana@yahoo.com.br

Received: December 07, 2019

Approved: April 02, 2020
How to cite: Santos LSS, Soares HS, Mascarenhas CS, Santos PRS, Gennari SM, Farias NAR. Serum anti-Toxoplasma gondii antibodies in Passer domesticus (Linnaeus, 1758) (Passeriformes: Passeridae), in the municipality of Pelotas, RS, Brazil. Braz J Vet Res Anim Sci. 2020;57(2):e164867. https://doi.org/10.11606/issn.1678-4456.bjvras.2020.164867

The coccidian Toxoplasma gondii (Nicolle \& Manceaux, 1909) is an obligate intracellular parasite widely distributed worldwide (Tenter et al., 2000). It is the etiological agent for 
toxoplasmosis, which is an important protozoan infection to both veterinarian and public health causing serious consequences for the health of homoeothermic animals and humans (Santos et al., 2015). Felids are responsible for environmental contamination because they are the only hosts that can excrete the oocysts, the highly resistant stage of the parasite in the environment, in their feces after ingesting the parasite (Dubey, 1995; Elmore et al., 2010).

Birds are important intermediate hosts for T. gondii, since they act as the source of infections for domestic and semi-domestic cats and/or free-living felids. Birds that constantly feed on the ground, such as chickens, pigeons, and house sparrows, may be good environmental contamination indicators/sentinels, since they are constantly exposed to ingestion of T. gondii oocysts (Waap et al., 2008; Gennari et al., 2014).

Passer domesticus (Linnaeus, 1758) (Passeriformes: Passeridae) is a terricolous non-migratory bird that adapts easily to agricultural, urban, and suburban environments. It takes advantage of anthropic activities by occupying places with buildings that are suitable for its shelter and for nesting (Major et al., 2004). House sparrows originated from Eurasia and northern Africa and were intentionally introduced into the Americas (Global Invasive Species Database, 2015). Today, they present dispersion throughout Brazilian territory (Sick, 1997).

Different species of Passeriformes, especially house sparrows, are commonly predated by felids (Churcher \& Lawton, 1987), which makes them essential for maintenance of the biological cycle of T. gondii and for the epidemiology of toxoplasmosis (Andrade et al., 2016). House sparrows from northeast Brazil were confirmed as intermediate hosts of T. gondii, reinforcing the potential importance of these birds on the transmission of the parasite to cats and other animals that may predate house sparrows (Gondim et al., 2010). In this context, the objective of this study was to detect the presence of anti-T. gondii antibodies among house sparrows in an urban area of the municipality of Pelotas, Rio Grande do Sul, southern Brazil (31 ${ }^{\circ} 45^{\prime} 55.44^{\prime \prime} S$ and $52^{\circ} 20^{\prime} 15.32^{\prime \prime} \mathrm{W}$ ).

Using mist nets (mesh of $30 \mathrm{~mm}$ ), 100 specimens of $P$. domesticus were caught in 13 places, used as a dormitory by the specie (public squares, gardens of private property and vacant lands) in the urban area of the municipality of Pelotas, Rio Grande do Sul, Brazil, between March 2016 and February 2018. Catching, transportation and euthanasia of the birds were done under a license granted by the Chico Mendes Institute of Biology and Conservation (ICMBio $\mathrm{n}^{\circ}$. 51118-3) and were approved by the Ethics Committee in Animal Experimentation of the Federal University of Pelotas (UFPel) (CEEA/UFPel nº. 4915).

After the birds were caught, they were transported in suitable cages to the Parasitology Laboratory (UFPel), where they were subjected to euthanasia through managed inhalational anesthesia, as prescribed by Resolution $n^{\circ} .1000 / 2012$ of the Federal Council of Veterinary Medicine of Brazil (Conselho Federal de Medicina Veterinária, 2012). After sedation, blood sampling was performed on the birds individually. The blood collection was performed by cardiac puncture. The collected blood samples were then centrifuged ( $2500 \mathrm{rpm}$ for $10 \mathrm{~min}$ ), and the serum from these samples was subsequently aliquoted, identified, and frozen at $-20^{\circ} \mathrm{C}$ until processing for serological tests.

The samples were sent to the Department of Preventive Veterinary Medicine, Faculty of Veterinary Medicine, University of São Paulo, São Paulo, Brazil, where they were analyzed by modified agglutination test (MAT), to investigate anti-T. gondii antibodies. The MAT was performed as described by Dubey \& Desmonts (1987), with 1:5 as the cut-off point (Dubey et al., 2016). Positive samples were tested at base-two serial dilutions until reaching the last positive dilution. Positive and negative chicken controls serum were included in each test.

Among the 100 serum samples analyzed, $80(80 \%)$ reacted to T. gondii, with a titre of 5 in two samples, 10 in six samples, 20 in 21 samples, 40 in 29 samples, 80 in 13 samples, 160 in eight samples and 320 in one sample. In all 13 locations, at least one bird was positive for T. gondii (Table 1).

In comparison with similar studies on $P$. domesticus, the occurrence of T. gondii antibodies among house sparrows in this urban area in southern Brazil was relatively high, reaching 80\% (80/100). In Europe, Uterák et al. (1992), using the Sabin-Feldman dye test, found an occurrence of 0.5\% (10/1907) among house sparrows in the Czech Republic. In Poland and in the Czech Republic, Literák et al. (1997) demonstrated the presence of anti- $T$. gondii antibodies, by means of the indirect fluorescent antibody test (IFAT), in $12.3 \%(28 / 227)$ of the house sparrows and $4.9 \%(2 / 41)$ of the Eurasian tree sparrow (Passer montanus Linnaeus, $1758)$ tested. In Lanzhou, northwest China, Cong et al. (2013) obtained a prevalence of $12.46 \%$ (39/313) by MAT. In Brazil, by means of the indirect hemagglutination test (HAI), antibodies against T. gondii were found in $1.02 \%$ $(3 / 293)$ of the house sparrows tested in the states of Bahia and Pernambuco (Gondim et al., 2010), and in 60.3\% (91/151) of the house sparrows that were caught on poultry farms in Pernambuco, also using HAI (Vilela et al., 2011). 
Table 1 - Detection of anti-Toxoplasma gondii antibodies in house sparrows (Passer domesticus, Linnaeus, 1758) (Passeriformes: Passeridae) collected from 13 locations in the urban area of Pelotas, Rio Grande do Sul, Brazil

\begin{tabular}{|c|c|c|c|}
\hline \multirow{2}{*}{$\begin{array}{l}\text { Capture } \\
\text { locations }\end{array}$} & \multicolumn{2}{|c|}{$n^{\circ}$ of house sparrows } & \multirow{2}{*}{$\begin{array}{c}\text { Occurrence } \\
\text { (\%) }\end{array}$} \\
\hline & Sampled & Positives & \\
\hline 1 & 9 & 7 & 77.7 \\
\hline 2 & 3 & 3 & 100 \\
\hline 3 & 16 & 16 & 100 \\
\hline 4 & 7 & 4 & 57.1 \\
\hline 5 & 3 & 1 & 33.3 \\
\hline 6 & 4 & 4 & 100 \\
\hline 7 & 14 & 11 & 78.5 \\
\hline 8 & 11 & 9 & 81.8 \\
\hline 9 & 8 & 3 & 37.5 \\
\hline 10 & 16 & 13 & 81.25 \\
\hline 11 & 5 & 5 & 100 \\
\hline 12 & 1 & 1 & 100 \\
\hline 13 & 3 & 3 & 100 \\
\hline Total & 100 & 80 & 80.0 \\
\hline
\end{tabular}

The variation in the rate of occurrence between these different studies needs to be evaluated carefully because of the different techniques and cut-off points that were used in the studies. According to Dubey (2010), the MAT is one of the most sensitive tests for detecting anti-T. gondii antibodies in human and animal serum (Dubey et al., 2016). Moreover, because there is no need for specific species of antibodies, it is very convenient for making the diagnosis in non-domestic hosts, such as house sparrows, for which no commercialized specific antibodies are available.

Literák et al. (1999) infected house sparrows with T. gondii and observed a peak of antibodies at 7 weeks post-infection (p.i.) and a reduction of the antibody titers at 12 weeks p.i. This observation, associated with the relatively high occurrence of positive birds found in the present study, increases the importance of this species in the region.

There are no data regarding seropositivity rates for T. gondii among domestic and semi-domestic cats and/or

\section{References}

Andrade LHM, Lugarini C, Oliveira RAS, Silva LTR, Marvulo MFV, Garcia JE, Dubey JP, Silva JCR. Ocorrência de anticorpos anti-Toxoplasma gondii em aves silvestres de três Unidades de Conservação Federais da Paraíba e da Bahia. Pesq Vet Bras. 2016;36(2):103-7. http://dx.doi. org/10.1590/S0100-736X2016000200007.

Conselho Federal de Medicina Veterinária (Brasil). Resolução n. 1000, de 11 de maio 2012. Dispõe sobre procedimentos e métodos de eutanásia em animais e dá outras providências. of free-living felids in the region of the present study. However, in terms of ground contamination in public squares in housing complexes in the city of Pelotas, there is a study that found oocysts of this protozoan in $33.3 \%$ $(13 / 39)$ of the squares sampled (Tavares et al., 2008). It is also known that $18.18 \%(20 / 110)$ of the dogs that were taken for attention at the UFPel Veterinary Hospital, were HAI seropositive for T. gondii (Faria Santos et al., 2012), and Santos et al. (2015) found that $84.3 \%$ (91/108) of the cats in the municipality have free access to the streets. These data, associated with the findings of the present study, indicate that house sparrows may serve as a source of $T$. gondii infection for other animals, including felids and canids. These birds are potential reservoirs and good indicators for T. gondii transmission.

\section{Conflict of Interest}

The authors state that they have no conflicts of interest to declare.

\section{Ethics Statement}

License granted by the Chico Mendes Institute of Biology and Conservation (ICMBio ${ }^{\circ}$. 51118-3) and were approved by the Ethics Committee in Animal Experimentation of the Federal University of Pelotas (UFPel) (CEEA/UFPel $\left.n^{\circ} .4915\right)$.

\section{Acknowledgements}

The authors thank teacher Cynthia Nunes Milanezi and student Wedmim Paixão Layber of the English Translation and Revision Laboratory of the Federal Institute of Espírito Santo, Guarapari campus, Espírito Santo, Brazil, for providing this extension service, and Prof. Dr. Solange Maria Gennari, scientific productivity bursary holder from the Conselho Nacional de Desenvolvimento Científico e Tecnológico (CNPq), Brazil.
Portal CFMV. Legislação [Internet]. Brasília (DF): CFMV, 2013 [cited 2020 Jun 5]. Available from: http://portal.cfmv. gov.br/lei/index/id/326.

Churcher PB, Lawton JH. Predation by domestic cats in an English village. J Zool. 1987;212(3):439-55. http://dx.doi. org/10.1111/j.1469-7998.1987.tb02915.x.

Cong W, Huang SY, Zhou DH, Zhang XX, Zhang NZ, Zhao $\mathrm{Q}$, Zhu XQ. Prevalence and genetic characterization of 
Toxoplasma gondii in house sparrows (Passer domesticus) in Lanzhou, China. Korean J Parasitol. 2013;51(3):363-7. http://dx.doi.org/10.3347/kjp.2013.51.3.363. PMid:23864750.

Dubey JP. Duration of immunity to shedding of Toxoplasma gondii oocysts by cats. J Parasitol. 1995;81(3):410-5. http:// dx.doi.org/10.2307/3283823. PMid:7776126.

Dubey JP. Toxoplasmosis of animals and humans. Boca Raton: CRC Press; 2010.

Dubey JP, Desmonts G. Serological responses of equids fed Toxoplasma gondii oocysts. Equine Vet J. 1987;19(4):3379. http://dx.doi.org/10.1111/j.2042-3306.1987.tb01426.x. PMid:3622463.

Dubey JP, Laurin E, Kwowk OCH. Validation of the modified agglutination test for the detection of Toxoplasma gondii in free-range chickens by using cat and mouse bioassay. Parasitology. 2016;143(3):314-9. http://dx.doi.org/10.1017/ S0031182015001316. PMid:26625933.

Elmore SA, Jones JL, Conrad PA, Patton S, Lindsay DS, Dubey JP. Toxoplasma gondii: epidemiology, feline clinical aspects, and prevention. Trends Parasitol. 2010;26(4):190-6. http://dx.doi.org/10.1016/j.pt.2010.01.009. PMid:20202907.

Faria Santos LMJ, Cademartori BG, Almeida IA, Krause E, Farias NAR, Ruas JL. Ocorrência de anticorpos IgG anti-Toxoplasma gondii em soros de cães atendidos no Hospital Veterinário da Universidade Federal de Pelotas - RS - Brasil. The Biologist. 2012;10(2).

Gennari SM, Ogrzewalska M, Soares HS, Saraiva DG, Pinter A, Labruna MB, Dubey JP. Occurrence of Toxoplasma gondii antibodies in birds from Atlantic Forest, state of São Paulo, Brazil. Vet Parasitol. 2014;200(1-2):193-7. http:// dx.doi.org/10.1016/j.vetpar.2013.10.003. PMid:24332961.

GISD: Global Invasive Species Database. Species profile Passer domesticus [Internet]. Paris: Invasive Species Specialist Group; 2015 [cited 2018 Nov 28]. Available from: http:// www.iucngisd.org/gisd/species.php?sc $=420$

Gondim LSQ, Abe-Sandes K, Uzêda RS, Silva MAS, Santos SL, Mota RA, Vilela SMO, Gondim LFP. Toxoplasma gondii and Neospora caninum in sparrows (Passer domesticus) in the northeast of Brazil. Vet Parasitol. 2010;168(1-2):121-4.http:// dx.doi.org/10.1016/j.vetpar.2009.09.055. PMid:19879051 . house sparrows (Passer domesticus) and tree sparrows (P. montanus). Avian Pathol. 1997;26(4):823-7. http:// dx.doi.org/10.1080/03079459708419255. PMid:18483947.

Literák I, Sedlák K, Juřicová Z, Pavlásek I. Experimental toxoplasmosis in house sparrows (Passer domesticus). Avian Pathol. 1999;28(4):363-8. http://dx.doi. org/10.1080/03079459994623. PMid:26905493.

Major I, Sales LG Jr, Castro R. Aves da caatinga. Fortaleza: Edições Demócrito Rocha; 2004.

Santos LSS, Carvalho AM, Aguiar CLG, Cademartori BG, Farias NAR. Seroprevalence and factors associated with Toxoplasma gondii infection in humans and its relationship with contact with domestic cats (Felis catus) in southern Rio Grande do Sul. Rev Patol Trop. 2015;44(2):135-45. http://dx.doi.org/10.5216/rpt.v44i2.36640.

Sick H. Ornitologia brasileira. Rio de Janeiro: Nova Fronteira; 1997.

Tavares ALC, Scaini CJ, Müller G, Farias NAR, Berne MEA. Contaminação do solo de praças de conjuntos habitacionais por helmintos e protozoários em Pelotas, Rio Grande do Sul, Brasil. Vittalle. 2008;20(1):59-63.

Tenter AM, Heckeroth AR, Weiss LM. Toxoplasma gondii: from animals to humans. Int J Parasitol. 2000;30(12-13):121758. http://dx.doi.org/10.1016/S0020-7519(00)00124-7. PMid:11113252.

Uterák I, Hejlíček K, Nezval J, Folk Č. Incidence of Toxoplasma gondii in populations of wild birds in the Czech Republic. Avian Pathol. 1992;21(4):659-65. http:// dx.doi.org/10.1080/03079459208418887. PMid:18670984.

Vilela SMO, Silva JSA, José WP Jr, Moraes EPBX, Saukas TN, Gondim LFP, Mota RA. Sparrows (Passer domesticus L.) as intermediary hosts of Toxoplasma gondii in poultry farms from the "agreste" region of Pernambuco, Brazil. Pesq Vet Bras. 2011;31(2):169-72. http://dx.doi.org/10.1590/ S0100-736X2011000200013.

Waap H, Vilares A, Rebelo E, Gomes S, Ângelo H. Epidemiological and genetic characterization of Toxoplasma gondii in urban pigeons from the area of Lisbon (Portugal). Vet Parasitol. 2008;157(3-4):306-9. http://dx.doi.org/10.1016/j. vetpar.2008.07.017. PMid:18722717. 